Annals of Warsaw University of Life Sciences - SGGW

Land Reclamation No 48 (4), 2016: 365-375

(Ann. Warsaw Univ. Life Sci. - SGGW, Land Reclam. 48 (4), 2016)

\title{
Structure investigations of layered soil - varved clay
}

\author{
MATYLDA TANKIEWICZ \\ Faculty of Civil Engineering, Wroclaw University of Technology
}

\begin{abstract}
Structure investigations of layered soil - varved clay. In the paper the results of laboratory investigations of structure of layered soil are presented. They focus on varved clay that is a soil composed of two alternately arranged varves with different texture and mechanical properties. An effect of such structure is an anisotropy of the material. Due to varying conditions during its formation process the soil exhibits some irregularities in composition and structure. Due to that modelling of mechanical behavior, like strength, may not provide satisfactory results. Main purpose of the examinations is an investigation of internal structure of layered soil - varved clay - in relation to its strength anisotropy and evaluation of the suitability of the use of two different techniques to assess the soil structure. Investigated material have been taken from area near city of Bełchatów in central Poland. The examinations included investigation of particle size distribution of soil and its components, identification of lamination with use of scanning electron microscope (SEM) and computed microtomography technique $(\mu \mathrm{CT})$. First, the texture of each varve and varved clay as a composite have been estimated. Next, the investigation of surface perpendicular to the lamination have been carried out with SEM. Pictures of varves with different magnifications are presented. Also the varves arrangement and details of layers contact area are shown. Finally, investigation of internal structure of the soil have been performed by using microtomograph. The outcome is a series of radiographic images and reconstructed $3 \mathrm{D}$ model of tested soil. Presented results show complexity of the structure of varved clay that affect the mechanical behavior. Determination of the structure with use of presented techniques may be helpful in examination of strength properties and proper modeling of such soil.
\end{abstract}

Key words: varved clay, layered soil, structure, scanning electron microscopy, microtomography

\section{INTRODUCTION}

Varved clay is a clayey sedimentary soil, formed in glacier lakes, with visible layering. It is composed of two periodically repeated layers: dark (silty-clayey) and bright (silty-sandy) ones. During warm periods, when the glacier was melting, deposits were carried into the lake where coarser particles were deposited and composed light varves. In cold periods, when the lake was frozen, fine particles precipitate forming dark varves. The investigations of properties and structure of varved clays have been conducted by many authors. The characteristic and basic geotechnical parameters of Connecticut Valley varved clay have been described by De Groot and Lutenegger (2005). Similar scope of research have been presented by Lu et al. (2013) for deposits occurred along the Delaware River. In turn, Petterson et al. (1993) focus on variability of varve thickness of the varved clay in northern Sweden. Varved clay occurred in Poland have been investigated, i.e. by Myślińska (1965) and Kostrzewski and Florkiewicz (1995). 
The consequence of layered structure is an anisotropy of mechanical behavior of the material. However, varying sedimentation conditions during its formation process cause irregularities in structure of the soil. Each varve can have different texture, thickness and mechanical properties. Due to this testing of mechanical properties, like strength, of such soil is troublesome. Moreover, it is difficult to generate directional failure characteristics, like for layered rocks (Ramamurthy 1993, Duveau et al. 1998), with adequate confidence. Due to this also modelling of mechanical behavior of the material is not a trivial issue. Main purpose of the examinations are an investigation of internal structure of layered soil - varved clay - in relation to its strength and evaluation of the suitability of the use of different techniques to assess the soil structure.
The article deals with varved clay occurred near city of Bełchatów, in central part of Poland. The laboratory examinations included investigation of particle size distribution of soil and its component varves, identification of lamination by using scanning electron microscope (SEM) and computed microtomography technique $(\mu \mathrm{CT})$. The following study focuses on macro scale, i.e. the layering and its possible impact on mechanical behavior of the material.

\section{MATERIAL AND METHODS}

The samples of varved clay were taken from an open-cast mine KWB Bełchatów, from the depth nearly $30 \mathrm{~m}$ below original ground level. Tested material, presented in Figure 1, is composed of dark layers with thickness up to about $5 \mathrm{~mm}$ and very thin bright varves. The results of investigations of strength ani-

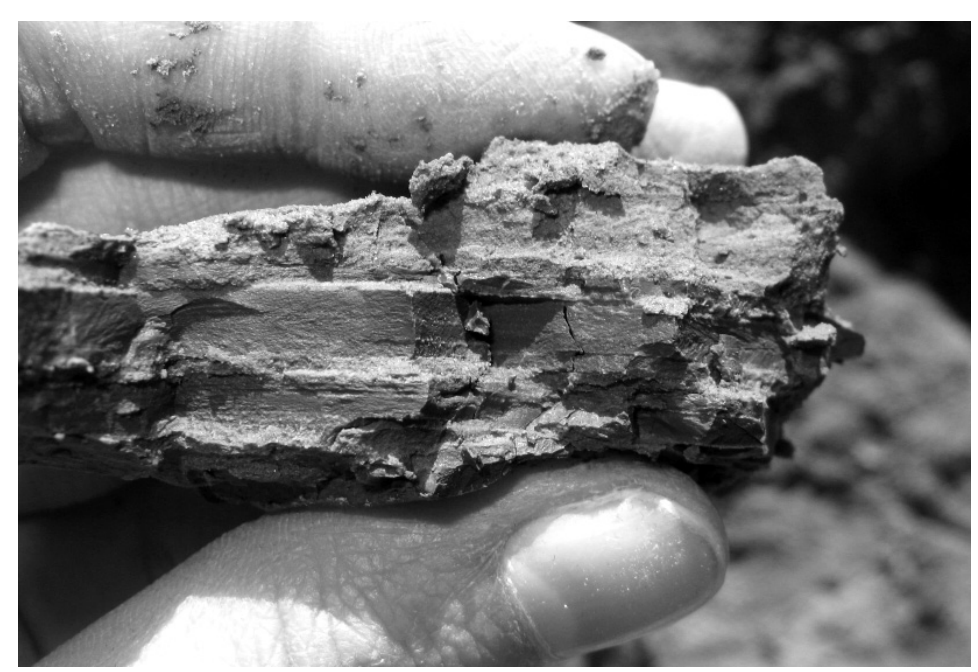

FIGURE 1. Varved clay and its laminated structure 
sotropy of the soil were presented earlier by Łydżba and Tankiewicz (2012) and Tankiewicz (2015a, b). Based on series of triaxial tests performed for different confinement and sample orientation author established directional failure characteristics for the material. The soil exhibits a high strength anisotropy that is associated mainly with occurring failure mode. Specimen may collapse by slipping across or along the varves, but in many cases the mechanism is more complex. It have been noticed that even for particular confinement and sample orientation the large scattering of estimated strength values is quite large. Utilization of normalization procedure improves the results, however, the scatter still can be observed, especially for lower confinement. Therefore, investigation of structure and composition of the material have been performed.

The particle size distributions of varved clay as a unity and bright and dark varves separately are presented in Table. The data have been obtained from three different representative samples taken for each varve and the varved clay. The analysis have been carried out with hydrometer method according to PKN-CEN ISO/
/TS 17892-4:2009. Classification of samples have been conducted in accordance with PN-EN ISO 14688:2006 and PN-EN ISO 14688-2:2006/Ap2:2012. The texture of dark varves is quite uniform. Dark layers consist mainly of clay fraction (diameter below $0.002 \mathrm{~mm}$ ) and silt fraction $(0.002-0.063 \mathrm{~mm})$ and they have been classified as a clay $(\mathrm{Cl})$. The composition of bright layers is more variable, but the main fraction is silt. The percentage amount of sand $(0.063-2 \mathrm{~mm})$ is between 5.7 and $22.9 \%$. The amount of silt is between 52.5 and $71.8 \%$, for clay fraction it is around $20 \%$. They have been defined as a silty clay $(\mathrm{siCl})$ or sandy silty clay (sasiCl). For varved clay the amount of sand, silt and clay is 2.4-3.6, 53.2-67.7 and 28.7-44.4\%, respectively. It can be named as a clay $(\mathrm{Cl})$ or silty clay $(\mathrm{siCl})$. The texture of varved clay isn't proportional to the texture of its constituents, which suggest that the percentage share of both varves is also various.

In order to determine the structure of the soil a series of laboratory tests have been conducted. First, the examinations with scanning electron microscopy (SEM) have been made. The instrument,

TABLE. The texture of tested material

\begin{tabular}{|l|c|c|c|c|c|}
\hline \multirow{2}{*}{ Texture } & \multicolumn{4}{|c|}{ Fraction content (\%) } & \multirow{2}{*}{ Type of soil } \\
\cline { 2 - 6 } & $\begin{array}{c}\text { sand } \\
0.063-2 \mathrm{~mm}\end{array}$ & $\begin{array}{c}\text { silt } \\
0.002-0.063 \mathrm{~mm}\end{array}$ & $\begin{array}{c}\text { clay } \\
<0.002 \mathrm{~mm}\end{array}$ & $\begin{array}{c}\text { silt + clay } \\
<0.063 \mathrm{~mm}\end{array}$ & \\
\hline Dark varves & $0.2-0.4$ & $36.5-51.2$ & $48.6-63.1$ & $99.6-99.8$ & $\mathrm{Cl}$ \\
\hline Light varves & $5.7-22.9$ & $52.5-71.8$ & $18.7-24.6$ & $77.1-94.3$ & $\mathrm{siCl} / \mathrm{sasiCl}$ \\
\hline Varved clay & $2.4-3.6$ & $53.2-67.7$ & $28.7-44.4$ & $96.4-97.6$ & $\mathrm{Cl} / \mathrm{siCl}$ \\
\hline
\end{tabular}


utilizing an electron beam, permits observation and characterization of a material and its surface. This technique is widely used in geosciences since the 1970s (Collins and McGown 1974, Al-Rawas and McGown 1999, Romero and Simms 2008). The images of varved clay from different parts of Poland have been presented by Grabowska-Olszewska et al. (1984). However, in the study authors focus on microstructure of soils. In this paper rather the macro scale, i.e. lamination thickness and its arrangement is considered. The investigations have been made with tabletop microscope TM3030 Hitachi on four representative samples with dimensions $20 \times 20 \times 20 \mathrm{~mm}$. Investigated surface has been perpendicular to the lamination.

Next, a non-destructive imaging method - computed microtomography $(\mu \mathrm{CT})$ - have been used. It is rapidly evolving technique that allows visualization of internal structure of materials. A series of radiographic images is used to reconstruct a three-dimensional model of scanned object. The images record differences in the degree of X-ray absorption, which depends on electron density, energy of the radiation, and bulk density of the material (Ketcham and Carlson 2001). The description of the technique and its applications were presented, i.a. by Taud et al. (2005), Lenoir et al. (2007), Pires et al. (2010). The examinations have been carried out with SkyScan1172 high-resolution X-ray microtomograph on representative specimen with diameter $38 \mathrm{~mm}$ and height around $30 \mathrm{~mm}$. The lamination angle specified macroscopically was $15^{\circ}$. For attenuation evaluation purpose the sample with dimension $10 \times 10 \times 10 \mathrm{~mm}$ was used.

\section{RESULTS AND DISCUSSION}

Microscopic observations using SEM allowed to identify the layering of tested soil. The material was observed at various magnifications and different settings in order to achieve the best images. The first observation was the differences in images of dark and light varves due to different texture of it. In Figure 2a the views of bright varves are presented at magnifications $250,800,2,000$. Figure $2 b$ shows the views of dark varves at the same values of magnifications. For silty-sandy light layers grains are clearly visible. During tests they have been measured and their diameter is between $30 \mu \mathrm{m}$ $(0.03 \mathrm{~mm})$ and $200 \mu \mathrm{m}(0.2 \mathrm{~mm})$. That corresponds to the diameters of sand and silt fractions. Clayey-silty dark varves at this magnifications seems homogenous, what is associated with much smaller diameters of particles constituting them. The size of silt particles is from 2 to $63 \mu \mathrm{m}$ and for clay particles it is below $2 \mu \mathrm{m}$. At greater magnifications they were also observed.

During the investigations it was confirmed that a thickness of varves is variable. The thickest layers have up to $5 \mathrm{~mm}$, but it was impossible to measure the thinnest ones without additional equipment. With the aid of microscope 
a
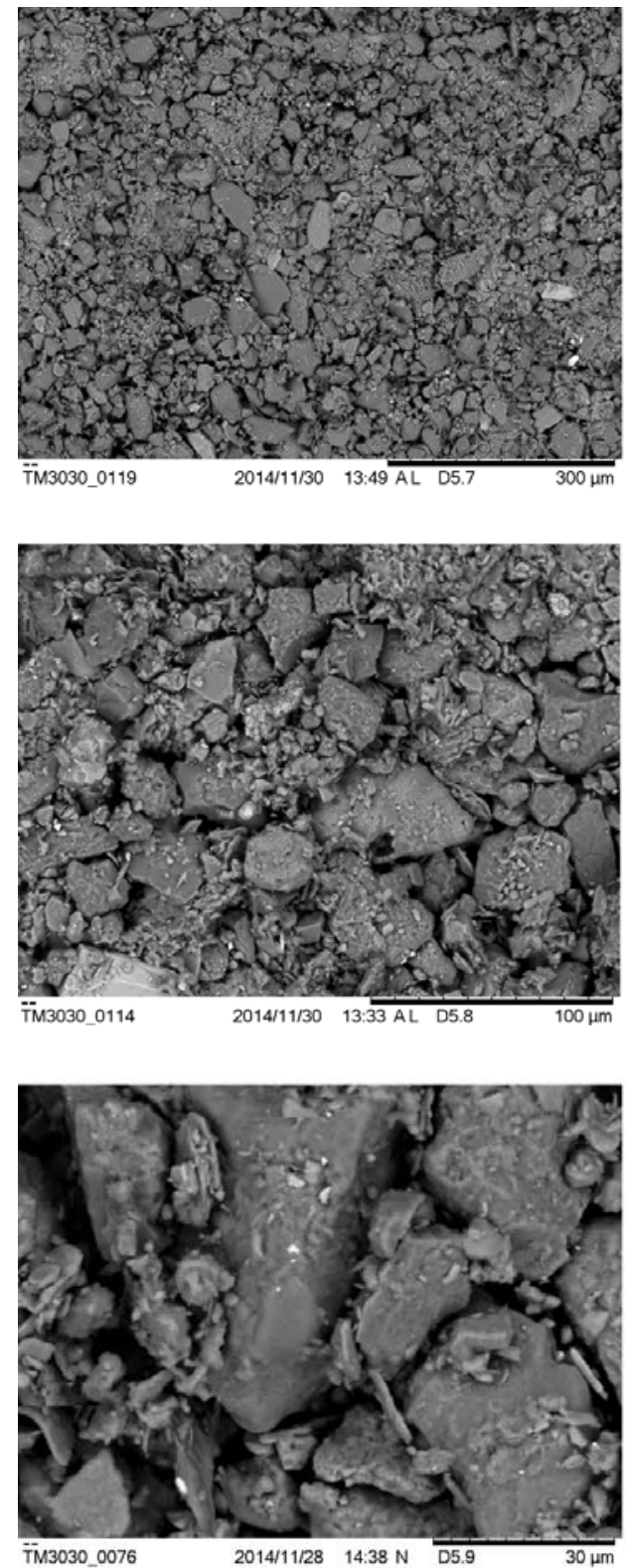

b
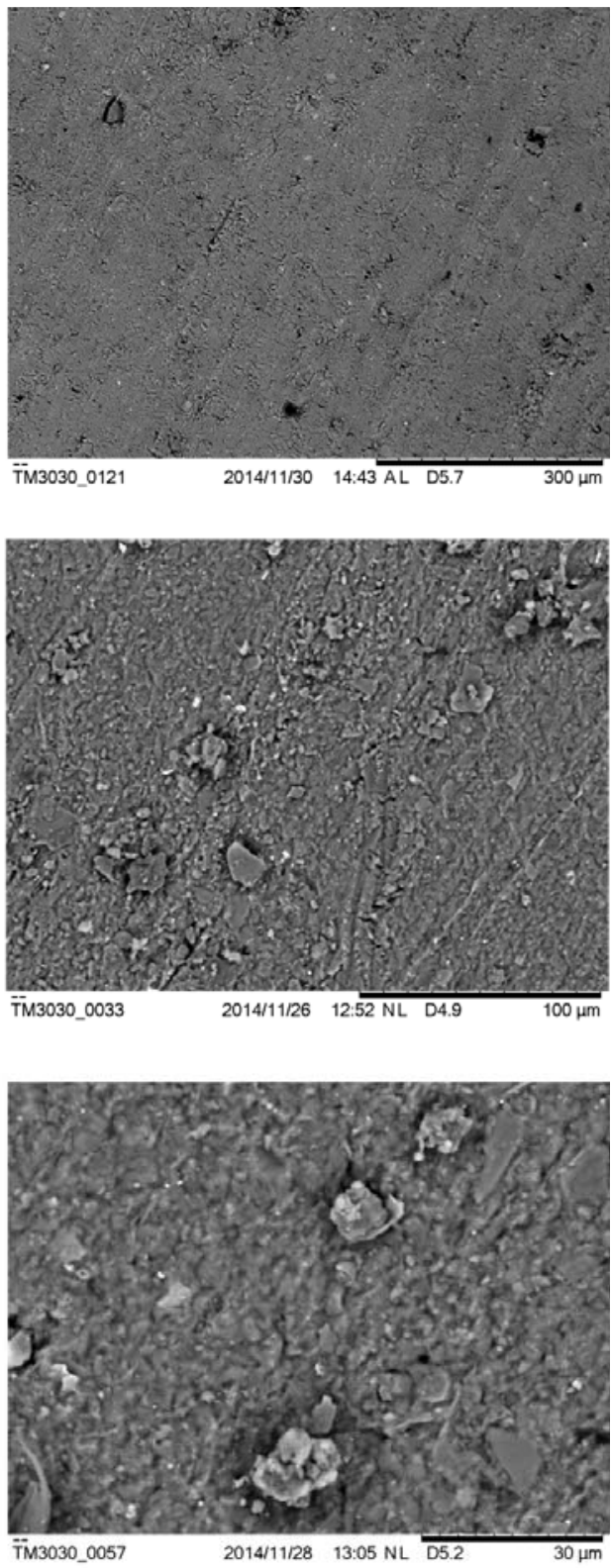

FIGURE 2. View of layers for magnifications 250, 800, 2,000: (a) bright silty-sandy, (b) dark clayey

they have been identified and measured. is about $150-200 \mu \mathrm{m}$. The precise measThe images of stratification are provided in Figure 3. Thickness of thinnest varves urement of the thickest layers was not possible due to size of observation field 


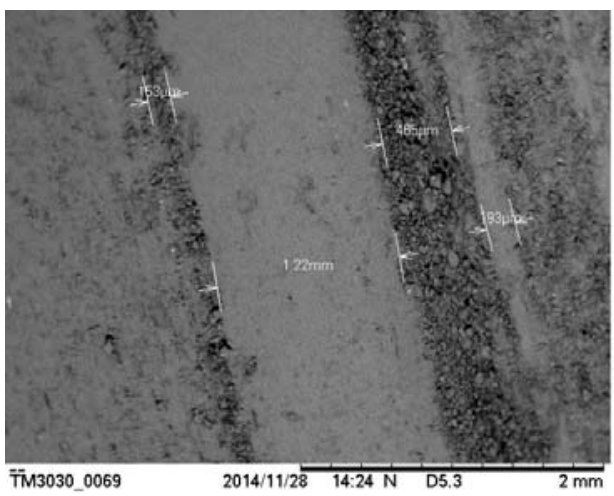

FIGURE 3. View of stratification of the varved clay

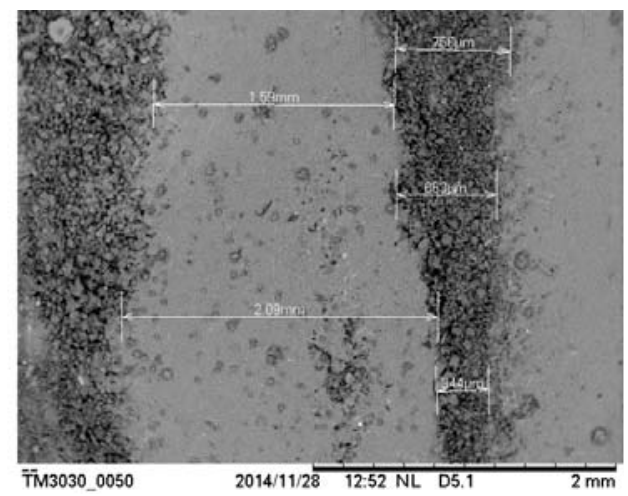

with voltage $89 \mathrm{kV}$, exposure time $960 \mathrm{~ms}$, rotation step $0.15^{\circ}$ and applying an aluminum and copper filter. The outcomes of $\mu \mathrm{CT}$ scanning are presented in Figure 5. In the cross-sections (Fig. 5a) darker fields correspond to dark clayey varves and lighter ones - to sandy bright layers. In 3D reconstructed model (Fig. 5b) - colors are inversed. At both illustrations the layering is well visible. It is hard to distinguish specific varves, however, the general trend of lamination can be observed. Furthermore, it can be noticed that the stratification surfaces are not linear, but curved. Therefore, determining the precise orientation without such test is difficult, which may affect the evaluation of sample orientation and, in consequence, directional failure characteristics. Performing the internal structure examinations is necessary for the proper identification of the lamination trend. Nevertheless, taking account a non-linearity of lamination in modelling is problematic. 

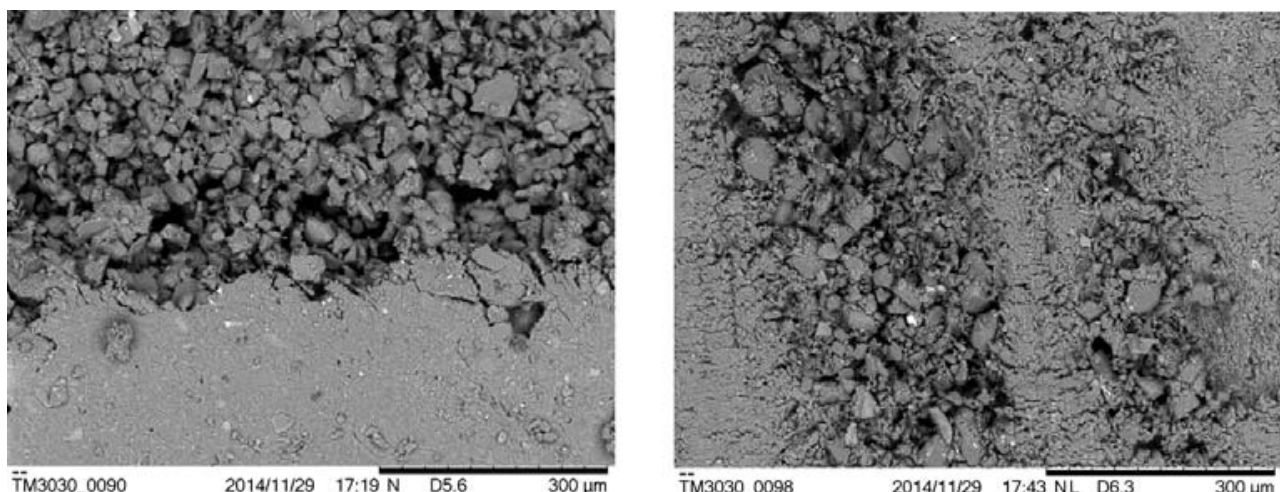

TMM3030_0098

2014/11/29 17:43 NL D6.3

$300 \mu \mathrm{m}$
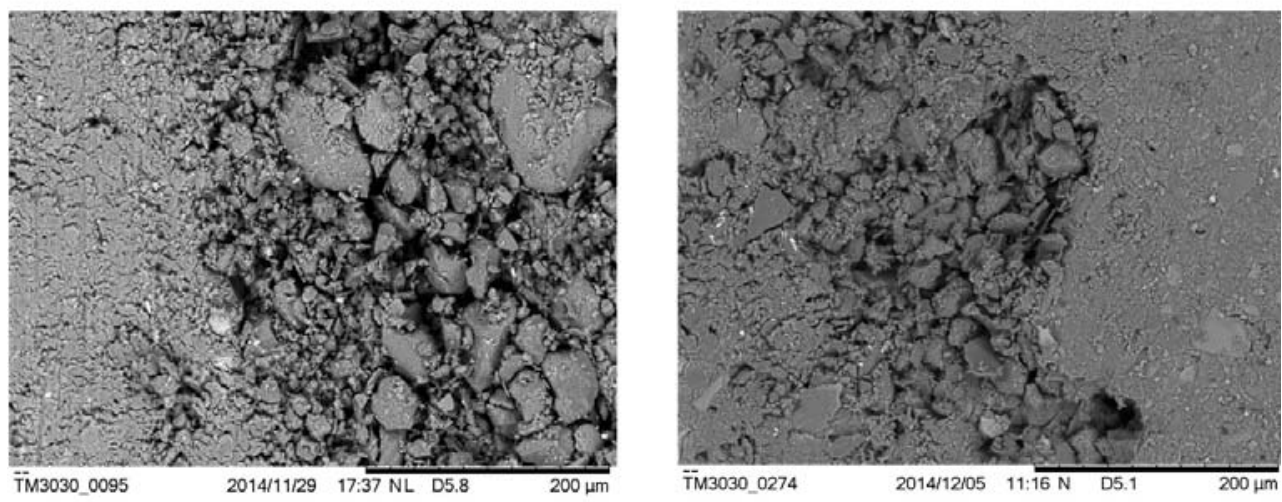

FIGURE 4. View of layers contact area

a
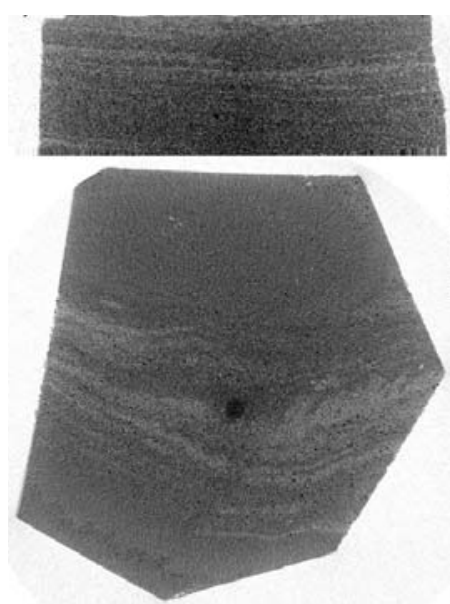

$\mathrm{b}$

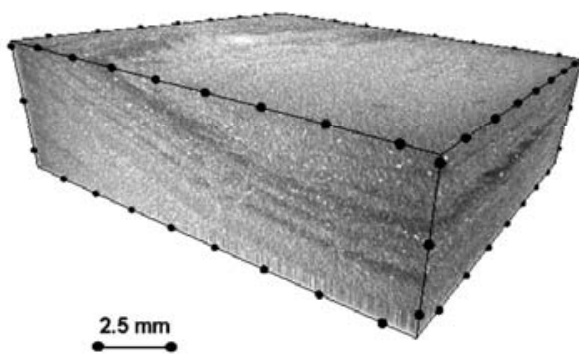

FIGURE 5. Results of $\mu \mathrm{CT}$ scanning: (a) cross-sections of the sample, (b) model 3D 
Next step was the separation of both types of varves by analysis of attenuation. The intensity of color in a greyscale in images created by $\mu \mathrm{CT}$ is associated with X-ray absorption rate. Based on the analysis of image and color distribution components of the object with different absorption coefficient can be distinguished. In Figure 6 the view of the sample and graph of brightness of pixels in a section through the height of specimen are provided. The value 0 in grayscale corresponds to black, i.e. material with the lowest radiation absorption - air. The higher values matches to higher absorbed radiation. In a single cross-section of dark clayey varve the values of color vary from 130 to 220 . For bright varve it is a little less, i.e. between 100 and 210. Analysis of full sample volume allows separation of layers in a cross-section through the lamination. At the height of the sample color value of each section have been averaged. In Figure 6a some cracks can be seen. They were formed due to long time of scanning procedure and, in consequences, drying of the sample. During analyses they were omitted. For dark layers the mean value of color is about 175 and for bright ones about 150. In Figure $6 \mathrm{~b}$ change in values is visible and consistent with the sample view. For the varves the attenuation differs and the transition between the layers is noticeable. However, it is indistinct and the difference in absorption is not very high.

Performed examinations allow to formulate the proposals for the evaluation of structure of layered soil in respect to

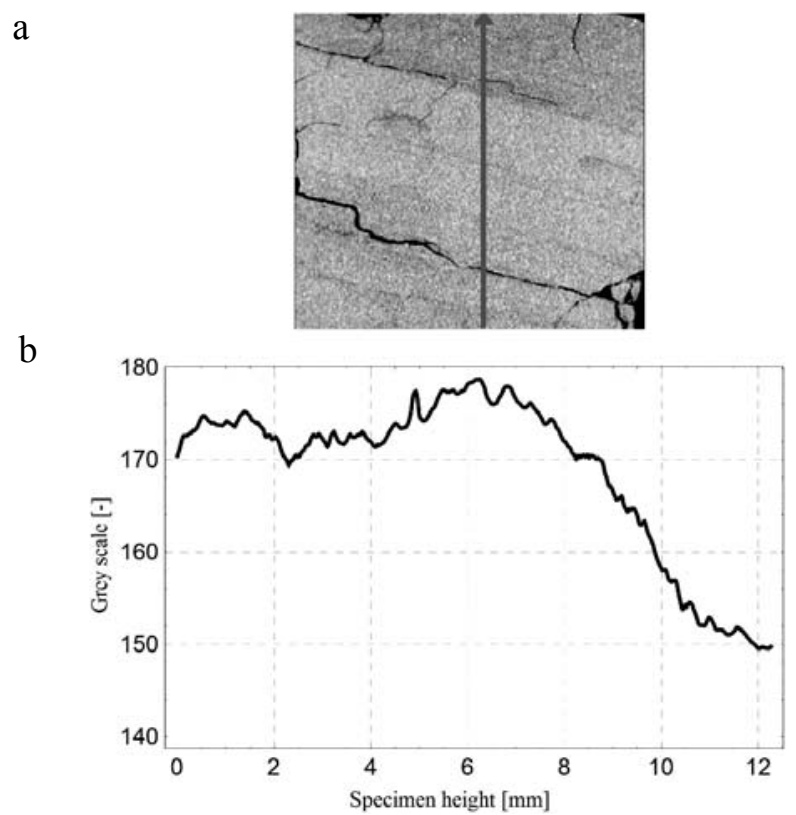

FIGURE 6. Attenuation for 3D sample: (a) view of specimen, (b) attenuation profile 
strength properties and modeling of the material. Estimation of varves arrangement with use of SEM might be helpful. In cases of two-component mathematical models for which is essential to determine the share of each component such test will be adequate. However, due to variable thickness of layers it would be necessary to conduct a number of tests. On the other hand, the microtomography can be a useful tool for evaluating the results of strength examinations. Before the test, it permits to visualize the internal structure and layering of the sample. In case on anisotropic material adequate identification of orientation of the specimen is very important and difficult during sample cutting. The advantage of this test is its nondestructive character so the specimen can be subjected to further tests. After the test, next scan may allow for determining the exact trajectory of the failure surface and its position with respect to the layering. Utilization of $\mu \mathrm{CT}$ for interpretation of shear strength test results for clayey soil have been presented earlier by Stefaniuk et al. (2014). Such approach would allow for better analysis of obtained strength results and taking into account structural effects on the modeling stage.

\section{CONCLUSIONS}

In the paper the results of laboratory examinations of structure of varved clay are presented. The study included tests with scanning electron microscope and microtomograph. Both techniques allowed for investigation of layered structure of the soil. Scanning electron microscopy is a tool permitting the evaluation of thickness of varves and its arrangement. In structure of investigated material a lot of irregularities have been observed. The layers in the soil have different and variable thickness and the contact between the layers is quite complex. Computed microtomography allowed for three-dimensional evaluation of stratification of the material, which turned out not to be planar. Such features of the material affect its strength and failure modes and impede proper modelling and predicting its mechanical behavior. Varved clay, on account of its formation process, have a complex structure that cannot be described by simple bi-component material with periodically repeated same layers. However, determination of the structure with use of presented techniques may be helpful in examination of strength properties and mathematical modeling of such layered material.

\section{REFERENCES}

Al-RAWAS A.A., McGOWN A. 1999: Microstructure of Omani expansive soils. Can. Geotech. J. 36 (2), 272-290.

COLLINS K., McGOWN A. 1974: The form and function of microfabric features in a variety of natural soils. Géotechnique 24 (2), 223-254.

De GROOT D.J., LUTENEGGER A.J. 2005: Characterization by sampling and in situ testing - Connecticut Valley varved clay. Stud. Geotech. Mech. 27 (3-4), 107-120.

DUVEAU G., SHAO J.F., HENRY J.P. 1998: Assessment of some failure criteria for strongly anisotropic geomaterials. Mech. Cohes.-Frict. Mater. 3 (1), 1-26. 
GRABOWSKA-OLSZEWSKA B., OSIPOV V., SOKOLOV V. 1984: Atlas of the microstructure of clay soils. PWN, Warszawa.

KETCHAM R.A., CARLSON W.D. 2001: Acquisition, optimization and interpretation of $\mathrm{X}$-ray computed tomographic imagery: applications to the geosciences. Comput. Geosci. 27 (4), 381-400.

KOSTRZEWSKI W., FLORKIEWICZ A. 1995: O interpretacji badań i opisie wytrzymałości osadów (iłów) warwowych. $Z N P P, B u d$. Lad. 40, 9-20.

LENOIR N., BORNERT M., DESRUES J., BESUELLE P., VIGGIANI G. 2007: Volumetric digital image correlation applied to X-ray microtomography images from triaxial compression tests on argillaceous rock. Strain 43 (3), 193-205.

LU Y., TAN Y., LIN G. 2013: Characterization of thick varved-clayey-silt deposits along the Delaware River by field and laboratory tests. Environ. Earth Sci. 69 (6), 1845-1860.

ŁYDŻBA D., TANKIEWICZ M. 2012: Preliminary study of failure anisotropy characterization of varved clay. AGH J. Mining Geoeng. 36, 229-234.

MYŚLIŃSKA E. 1965: Wpływ warunków sedymentacji i diagenezy iłów warwowych zlodowacenia środkowopolskiego na obszarze Mazowsza na ich właściwości inżyniersko-geologiczne. Biul. Geol. Geol. Wydz. Geol. UW 7 .

PETTERSON G., RENBERG I., GELADI P., LINDBERG A., LINDGREN F. 1993: Spatial uniformity of sediment accumulation in varved lake sediments in northern Sweden. J. Paleolimnol. 9 (3), 195-208.

PIRES L.F., BORGES J.A., BACCHI O.O., REICHARDT K. 2010: Twenty-five years of computed tomography in soil physics: A literature review of the Brazilian contribution. Soil Till. Res. 110 (2), 197-210.

PN-EN ISO 14688:2006. Geotechnical investigation and testing. Identification and classification of soil.

PN-EN ISO 14688-2:2006/Ap2:2012. Geotechnical investigation and testing. Identification and classification of soil. Part 2: classification rules.
PKN-CEN ISO/TS 17892-4:2009. Geotechnical investigation and testing. Laboratory testing of soil. Part 4: Determination of particle size distribution.

RAMAMURTHY T. 1993: Strength and modulus responses of anisotropic rocks In: J.A. Hudson (Ed.), Comprehensive Rock Engineering. Vol. 1. Fundamentals. Pergamon Press, Oxford, 319-329.

ROMERO E., SIMMS P.H. 2008: Microstructure investigation in unsaturated soils: a review with special attention to contribution of mercury intrusion porosimetry and environmental scanning electron microscopy. In: Laboratory and Field Testing of Unsaturated Soils. Springer, Netherlands, 93-115.

STEFANIUK D., TANKIEWICZ M., STRÓŻYK J. 2014: X-ray microtomography $(\mu C T)$ as a useful tool for visualization and interpretation of shear strength test results. Stud. Geotech. Mech. 36 (4), 47-55.

TANKIEWICZ M. 2015a: Badania laboratoryjne kierunkowej wytrzymałości gruntu warstwowego [Laboratory investigation of directional strength of layered soil]. Inż. Mor. Geotech. 3, 316-319.

TANKIEWICZ M. 2015b: Experimental Investigation of Strength Anisotropy of Varved Clay. Procedia Earth Planet. Sci. 15, 732-737.

TAUD H., MARTINEZ-ANGELES R., PARROT J.F., HERNANDEZ-ESCOBEDO L. 2005: Porosity estimation method by X-ray computed tomography. J. Petro. Sci. Eng. 47 (3), 209-217.

Streszczenie: Ocena struktury gruntu warstwowego - itu warwowego. W artykule przedstawiono wyniki badań laboratoryjnych struktury gruntu warstwowego. Analizowanym materiałem był ił warwowy - grunt zbudowany z dwóch naprzemiennie ułożonych warstw o różnych składzie granulometrycznym i parametrach mechanicznych. Efektem takiej budowy jest silna anizotropia ośrodka. Ponadto ze względu na zmienne warunki $\mathrm{w}$ trakcie procesu formowania, ił warwowy wykazuje pewne nieregularności w składzie i budowie warw. Wobec tego określenie wytrzymałości i identyfikacja modelu matematycznego dla takiego ośrodka są problematyczne. 
Celem badań był opis budowy iłu warwowego w odniesieniu do anizotropii wytrzymałości materiału oraz ocena przydatności dwóch różnych metod do określenia struktury gruntu warstwowego. Analizowany ił warwowy pochodził $\mathrm{z}$ terenów w okolicy Bełchatowa. Badania laboratoryjne obejmowały analizę granulometryczną gruntu oraz identyfikację struktury: powierzchniową, z wykorzystaniem elektronowego mikroskopu skaningowego (SEM), oraz przestrzenną, z wykorzystaniem nowoczesnej techniki obrazowania, tj. mikrotomografii komputerowej $(\mu \mathrm{CT})$. W pierwszej kolejności wykonano badanie składu granulometrycznego dla iłu warwowego, jako całości, oraz dla obu warw osobno. Następnie przeprowadzono wzrokową ocenę struktury z wykorzystaniem mikroskopu SEM. W efekcie otrzymano zdjęcia warstw ciemnej i jasnej przy różnych powiększeniach, obrazy przedstawiające układ warstwowania oraz szczegóły kontaktu warstw. Ostatnim krokiem było badanie w mi- krotomografie. Wynikiem takiego testu jest seria obrazów radiograficznych oraz zrekonstruowany model 3D skanowanego obiektu, co pozwoliło na przestrzenną identyfikację warstwowania. Uzyskane wyniki badań wskazują na dużą złożoność budowy iłu warwowego, co wpływa na jego mechaniczne właściwości. Wykorzystanie prezentowanych technik do oceny budowy gruntu może być pomocne w badaniach wytrzymałości oraz właściwym modelowaniu takiego gruntu.

\section{MS received September}

\section{Author's address:}

Matylda Tankiewicz

Wydział Budownictwa Lądowego i Wodnego

Politechnika Wrocławska

pl. Grunwaldzki, 50-377 Wrocław

Poland

e-mail: matylda.tankiewicz@pwr.edu.pl 